but applied to the upper lid. The effect of the operation here is to fill up the cavity with a soft pad covered with skin, which forms a support for the artificial eye. The first incision (Fig. 5) is made in the principal fold between the upper lid and the loose tissue above, and the flap is marked out with a short vertical cut upwards at each end of the incision. The flap is then dissected up as before and the original incision deepened until the conjunctiva of the upper fornix is reached. Then the flap is sutured to the posterior lip of the wound in the conjunctiva. A week or ten days afterwards the base of the flap is divided, the deep structures being included in the incision. The margin of the base is then slightly undermined, and sutured to the conjunctiva lining the lid. The flap and the tissues underneath it having lost their support above owing to division of the deeper structures, sink down behind the upper lid in the course of the next week or so.

Patients who require a vulcanite support behind the artificial eye always give it up sooner or later. The reasons are, that the socket alters its shape and the eye does not maintain its original position. In addition to this it is at the best of times a troublesome device. So it is discarded and a shade is worn to hide an empty socket and a sunken lid.

The operation enables the patient to wear an artificial eye in comfort without a special support, and although ptosis results, it is easily remedied as far as the position of the lid is concerned; and the patient can move about freely without drawing particular attention to himself.

\title{
ANGIOMA OF THE CHOROID.
}

BY

E. ERSKINE HENDERSON, LONDON.

THE interesting case recorded by Paton and Treacher Collins in last year's Transactions of the Ophthalmological Society (Vol. XXXIX, p. 157, 1919) induces me to record another case of what may turn out to be a similar condition, although the eye does not at present show any sign of coming under the pathologist.

The patient, E. H., a girl of eight, was first seen in 1917 on account of convergent strabismus of the left eye. This eye, which was considerably more hypermetropic than its fellow, had no central fixation and was quite amblyopic. The other eye had normal vision. The left side of the forehead, part of the eyelid, and temporal region were covered by a port wine naevus. The fundus at that time appeared normal. I' saw her again at the beginning of 1920 . 
She was sent as a routine matter of school inspection, and neither the patient nor her mother had noticed any alteration in the vision of the eye since her last visit. Vision was as before, but the retina on the left side was now completely detached. It was greyish in colour and did not appear at all solid. There was no vitreous opacity and the tension was normal. Should glaucoma supervene at a later date I hope to be able to obtain the specimen for examination.

The literature of angioma of the choroid is fairly extensive, going back as far as 1879 , but the number of cases in which it has been recorded as occurring in conjunction with naevus of the face are not very numerous. As it may be of assistance to others, I append a bibliography of all the cases I have been able to find up to 1915. Readers interested in the microscopical anatomy and other details of angioma of the choroid in general will find a good account and an extensive bibliography in the papers by Paton and Collins, and by Love, references to which are given.

\section{REFERENCES}

Milles.-"Naevus of the right temporal region; naevus of the choroid and detachment of the retina in the right eye." Trans. Ophthal. Soc. U.K., 1884, Vol. XXXI, p. 168.

Lawford.- "Naevus of left side of face ; naevus of choroid, subretinal haemorrhage, and detached retina in left eye." Trans. Ophthal. Soc. U.K., 1885, Vol. V, p. 136.

Galezowsiki. - "Naevus congénital sous forme de couperose occupant la face, le front et le cuir chevelu, avec buphtalmie monoculaire." Annales derm. et de Syph., Paris, 1898, Vol. IX, p. 249.

Wagenmann.- "Ueber ein cavernöses Angion der Aderhaut." Arch.f. Ophthal., 1900, Vol. LI, Pt. iii, p. 532.

Steffens.- "Ueber ein Angion der Aderhaut mit ausgedehnter Verknöckerung bei Teleangiektasie des Geschictes." Klin. Monatsbl. f. Augenheilk., 1902, Vol. XI, Pt. ii, p. 113.

Quackenboss and Verhoeff.-" Angioma of the choroid " Annals of Ophthal., October, 1908, Vol. XVII, p. 645; and Trans. Amer. Ophthal. Soc., 1908, Vol. XI, Pt. ii, p. 510.

Love.- "Simple angioma of the choroid." Arch. of Ophthal., 1914, Vol. XLIII,

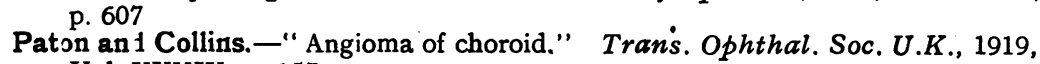
Vol. XXXIX, p. 157.

\section{ANNOTATIONS}

\section{The Medical Examination of Civilian Pilots, Navigators, and Engineers}

This pamphlet, issued by the Air Ministry " for the information of those, particularly in the Dominions and Colonies, who are now about to put into practice the principles laid down in the International Air Convention," is based upon the experience gained 